\title{
Acadiensis
}

Journal of the History of the Atlantic Region

Revue d'histoire de la région Atlantique

\section{Roots, Region, and Resistance: Facing Industrial Ruin in Sydney, Cape Breton, during Canada's Centennial Year}

\section{Andrew Parnaby}

Volume 48, numéro 1, 2019

URI : https://id.erudit.org/iderudit/1062176ar

DOI : https://doi.org/10.1353/aca.2019.0001

Aller au sommaire du numéro

Éditeur(s)

Department of History at the University of New Brunswick

ISSN

0044-5851 (imprimé)

1712-7432 (numérique)

Découvrir la revue

Citer cet article

Parnaby, A. (2019). Roots, Region, and Resistance: Facing Industrial Ruin in Sydney, Cape Breton, during Canada's Centennial Year. Acadiensis, 48(1). https://doi.org/10.1353/aca.2019.0001

\section{Résumé de l'article}

Le 13 octobre 1967 - le « Vendredi noir » - les propriétaires de la Dominion Steel and Coal Company (DOSCO) annoncèrent la fermeture imminente de l'aciérie de la compagnie à Sydney. Néanmoins, après une grande manifestation de la population locale, appelée la " Parade of Concern », le gouvernement provincial, grâce à une aide considérable du gouvernement fédéral, acheta l'usine de la DOSCO et la transforma en société d'État. Cette réponse centrée sur l'État à la désindustrialisation démontre l'importance économique, politique et culturelle que revêt le «lieu » dans les efforts pour éviter l'effondrement de l'industrie lourde, une réponse qui était complètement absente du contexte américain et qui n’était apportée qu'avec parcimonie dans le contexte canadien. 


\title{
Roots, Region, and Resistance: Facing Industrial Ruin in Sydney, Cape Breton, during Canada's Centennial Year
}

\author{
ANDREW PARNABY
}

\begin{abstract}
Le 13 octobre 1967 - le « Vendredi noir » - les propriétaires de la Dominion Steel and Coal Company (DOSCO) annoncèrent la fermeture imminente de l'aciérie de la compagnie à Sydney. Néanmoins, après une grande manifestation de la population locale, appelée la "Parade of Concern ", le gouvernement provincial, grâce à une aide considérable du gouvernement fédéral, acheta l'usine de la DOSCO et la transforma en société d'État. Cette réponse centrée sur l'État à la désindustrialisation démontre l'importance économique, politique et culturelle que revêt le « lieu » dans les efforts pour éviter l'effondrement de l'industrie lourde, une réponse qui était complètement absente du contexte américain et qui n'était apportée qu'avec parcimonie dans le contexte canadien.
\end{abstract}

On 13 October 1967 - "Black Friday" - the owners of the Dominion Steel and Coal Company (DOSCO) announced the imminent closure of the company's Sydney steel works. Yet after a massive community demonstration dubbed the "Parade of Concern," the provincial government, with significant federal assistance, purchased the plant from DOSCO and turned it into a provincial Crown corporation. This state-centred response to deindustrialization demonstrates the economic, political, and cultural importance of "place" in adverting the collapse of heavy industry, a response that was utterly absent in the American context and used only sparingly in the Canadian one.

\section{M.A. MACLELLAN, THE PRESIDENT OF ST. FRANCIS XAVIER} UNIVERSITY, was desperately worried about the future of Cape Breton Island. On 13 October 1967, the Dominion Steel and Coal Company (DOSCO) announced its intention to "disengage" from its Sydney steel operations in six months. In the anxious days and weeks that followed, a grassroots movement to save Sydney steel emerged locally, culminating in a massive community rally that brought roughly 20,00o people out in protest. Between these two momentous events, MacLellan wrote to Prime Minister Lester B. Pearson. He called for resistance and a "thunderous 'no'!" to corporate "irresponsibility" and the "inexorable dictate of economics." Otherwise, he reasoned, the future of the island was in jeopardy: "The closing of the steel plant would sound the death knell for industrial Cape Breton and it would lead to almost total depopulation of the industrial area. The demoralizing effect upon individuals,

Andrew Parnaby, "Roots, Region, and Resistance: Facing Industrial Ruin in Sydney, Cape Breton, during Canada's Centennial Year," Acadiensis 48, no. 1 (Spring/printemps 2019): 5-31. 
families, and other institutions would be beyond human calculation." Moving outward from these immediate consequences, MacLellan suggested that the full impact of the industrial crisis would not be confined to a single economic sector or region of the country. Indeed, left unresolved, it would undermine "regional parity and social justice" - and take national unity down with it. "Must we stand by helplessly while Canada's growth pattern crystallizes into several super powerful metropolitan centers and all life on the periphery is forced into an orbit of jeopardy?" he argued. "If this represents the way of life for which so many Canadians fought and died, and for which we wave the new flag in this Centennial Year, then all I can say is God help Canada. It can never save itself."

Few people in Cape Breton were shocked by the president's strong stance on the steel question. Not only did St. Francis Xavier University - through its Extension Department - possess a long history of social activism on the island that dated back to the 1920s, but MacLellan's understanding of provincial disparity, collective identity, and political action was by then widely shared - on the island and around the region. In the aftermath of DOSCO's devastating announcement - a moment that came to be known as "Black Friday" - a community-led effort to "save our industry" emerged. Influenced by MacLellan's colleague Father William Roach, an activist priest with a deep interest in co-operatives, the movement organized a large demonstration in early November. Modelled in part on the civil rights marches in the United States, it was called the "Parade of Concern." The unity and moral force of the community resistance was sustained by many things, not the least was the broad, shared sensibility that Cape Breton itself had to be defended against an exploitative, external foe - DOSCO's parent company, the UK-based multinational Hawker Siddeley. At the same time, sympathetic politicians at all levels of government mounted a lengthy challenge of their own; and they too looked to the mobilizing power of regional inequality to strengthen their call for political action.

Together, these efforts produced a far-reaching outcome: by early 1968, the provincial government, with federal assistance, had purchased the plant from DOSCO and converted it into a provincial Crown corporation. It had been "saved" - a state-driven solution to the collapse of heavy industry that was utterly absent from the American context and used only rarely in the Canadian one. How and why this unique outcome happened is the focus of this 
article. As the following analysis suggests, the economic, political, and cultural importance of "place" was critically important. ${ }^{2}$

\section{Liability}

The late 1960s, 1970s, and early 1980 os were especially hard for industrial workers and their communities in North America, even "cataclysmic" in the estimation of one study. ${ }^{3}$ Data from the United States is especially revealing. The profitability of American manufacturers declined steeply during this time frame; their share of global steel production contracted as well. Nearly 350,000 autoworkers lost their jobs between 1978 and 1982. Demographic collapse came to industrial cities like Youngstown (Ohio), Scranton (Pennsylvania), Niagara Falls (New York), and Detroit (Michigan), which had lost roughly 800,000 people before this turbulent period was over. ${ }^{4}$ By that time workers, journalists, and academics were talking about a "rust belt," a region of economic ruin that encompassed the upper mid-west, Great Lakes basin, and the northeastern corner of the continent. And "deindustrialization" - the sudden collapse of employment in resource extraction, heavy manufacturing, and value-added production within a short time frame within a defined location or region had become a key political issue. ${ }^{5}$ Cape Breton was on the leading edge of this structural transformation, as global pressures and local vulnerabilities combined to produce a crisis not seen since the island's Great Depression of 1923-39.

The unwinding of industrial Cape Breton was evident first in the context of coal. During the 1950s and early 1960s market share in Ontario and Quebec was lost to cheaper American options, slowdowns and shutdowns at local pits multiplied, and federal subsidies for the industry scaled higher - peaking in the 1960 s at about $\$ 3,000$ per miner per year. ${ }^{6}$ The conversion of trains from coal

2 My thinking on this issue was stimulated by lan McKay's "A Note on 'Region' in Writing the History of Atlantic Canada," Acadiensis XXIX, no. 2 (Spring 2000): 89-101 and George Orwell's Why I Write (New York: Penguin Books, 1984), 11-101.

3 "Cataclysmic" is Barry Bluestone's adjective for this time period. See his "Foreward" to Jefferson Cowie and Joseph Heathcott, eds., Beyond the Ruins: The Meanings of Deindustrialization (Ithaca, NY: Cornell University Press, 2003).

4 Robert Brenner, The Economics of Clobal Turbulence: A Special Report on the World Economy (London: New Left Review, 1998), 93; Steven High, Industrial Sunset: The Making of North America's Rust Belt, 1969-1984 (Toronto: University of Toronto Press, 2003), 6, 92-7; Steven High and David W. Lewis, Corporate Wasteland: The Landscape and Memory of Deindustrialization (Toronto: Between the Lines, 2007), 4; Judith Stein, Pivotal Decade: How the United States Traded Factories for Finance in the 1970s (New Haven: Yale University Press, 2010). I have written about this in greater depth in "Life Among the Ruins: Deindustrialization in Historiographical Perspective," Labour/Le Travail 72 (Fall 2013): $279-93$. Detroit's population in 1950 was $1,849,568$; by the end of the 1980 s it stood at $1,027,974$.

5 Brenner, Economics of Clobal Turbulence, 1, 54; Stein, Pivotal Decade, 74; Parnaby, "Life Among the Ruins," esp. 280-5.

6 A report produced for the Kennedy Round of CATT talks, which were held from 1962-1967, summarized the impact of the coal subsidies: "The provision of a market for this amount of coal has maintained mines in operation that could not survive if dependent on the local market alone; it has provided employment and maintained communities 
to diesel power played an important role in this unfolding regional coal crisis, and the repeal of the Coal Equality Act in 1960, which had paid Canadian steel makers to use Canadian coal for coking purposes, helped bring it to a head? DOSCO, which took ownership of most of the island's collieries in 1928, was under severe strain. Between 1940 and 1965 total coal production from mines in Nova Scotia contracted from 7.8 million tons per year to 4.3 million per year, a decline of 45 per cent. ${ }^{8}$ Many operations on the Nova Scotia mainland - at Springhill and Pictou - were already out of business before the end of the 1950s; so, too, were individual mines in Cape Breton at Inverness, Reserve, Sydney Mines, New Waterford, and Glace Bay. More closures followed. At least 14 additional mines closed on Cape Breton between 1950 and 1966, reducing the overall employment in the island's coal sector by nearly 40 per cent. ${ }^{9}$

The federal government was not unmoved by the crisis. A Royal Commission on Coal, under the direction of Justice Ivan Rand, was created in October of 1959. Its final report, which was released less than a year later, recommended a slow phasing out of coal as the main source of employment in the industrial regions of Cape Breton and a new focus on tourism and culture in order to help better "dissolve" the island's "climate of drabness and let into human hearts and intelligence the light of new interests, hopes and ambitions." ${ }^{\prime \prime}$ Spurred by the commission's assessment of the issues, government money subsequently flowed into the upgrading of Cape Breton Highlands National Park and the reconstruction of Fortress of Louisbourg the latter initiative getting underway in 1961 with a budget of $\$ 25$ million. Yet hardship, as one might expect, proliferated - prompting long-serving Cooperative Commonwealth Federation MLA for Cape Breton Centre Michael MacDonald to remark: "How far away are we from the 'Hungry Thirties'?"11 Not far, it seemed. By mid-decade, steelworkers reported levels of "extreme anxiety" and "great mental strain" reminiscent of the Great Depression. ${ }^{12}$ The unemployment rate on the island was thought to have been around 25 per cent, and an unemployed workers' union was operating in some of the industrial

in Eastern and Western Canada that would otherwise be derelict." See General Agreement on Tariffs and Trade, Subsidies, Notifications Pursuant to Article XVI:1, 2 April 1963 (p. 17).

7 Report of the Royal Commission on Coal (Ottawa: Queen's Printer, 1960), Figure 1, "Energy Supply in Canada," xvi.

8 J.R. Donald, The Cape Breton Coal Problem (Ottawa: Queen's Printer, 1966), 104.

9 K. Scott Wood and Harold Verge, A Study of the Problems of Certain Cape Breton Communities (Halifax: Institute of Public Affairs, 1966), 67-9, Table 9 and Table 10.

10 Report of the Royal Commission on Coal, 48.

11 J. Murray Beck, Politics of Nova Scotia, Volume 2, 1896-1988 (Tantallon, NS: Far East Publications, 1988 ), 270.

12 Martin Merner, USWA Local 1064, to Allan J. MacEachen, 8 June 1967, Lester Pearson Papers (LPP), MC 26 N4, vol. 45, file 217.31, Library and Archives Canada (LAC). 
areas. ${ }^{13}$ It was possible to hear people demanding "work, not relief" - a phrase reminiscent of the On-to-Ottawa trek.

The island's steel sector, another DOSCO asset, was similarly situated. German, Japanese, and Dutch steelmakers were closing off export markets to North American producers while dumping excess product in the United States and Canada at prices below market value. ${ }^{14}$ For DOSCO such international competitive challenges were intensified by the political economy of domestic steel production, which had become dominated by Ontario and Quebec. This regional consolidation of heavy production was pushed forward by many things, not the least of which were the wartime industrial policies of the federal government that successfully modernized and diversified central Canadian steel makers at the expense of the country's sole East Coast producer. While DOSCO's steel division remained profitable into the late 1940s and early 1950 , its margins were not only smaller than those tallied by STELCO in Hamilton and ALGOMA in Sault Ste. Marie but they grew at a significantly slower rate. Domestic market share fell in lockstep. In 1913, for example, Nova Scotia was responsible for 42.5 per cent of the steel made in Canada; by 1960, that number had fallen to 12.1 per cent. ${ }^{15}$ In retrospect, the war years appear pivotal. Longerterm, more structural challenges tied to the island itself made these broader, post-war international and national pressures more acute. Readily available coal from the island and iron ore from Newfoundland were of poor quality pushing the cost-per-ton-produced upward. And distance to markets in Central Canada made exports by rail nearly cost prohibitive without a significant federal subsidy. ${ }^{16}$ Not surprisingly, employment levels at the Sydney works which peaked at nearly 5,000 in 1945 - declined consistently as the 1950 s shaded into the 196os; temporary and extended layoffs were increasingly common. ${ }^{17}$ The "immediate future is bleak for the whole industrial area," observed Sydney

13 Maurice Keough, Unemployed Workers Union, to Pearson, undated, LPP, MG 26 N4, vol. 45, file 217.31, LAC.

14 Allegations of dumping can be found in "Tariff Reduction not 'good excuse' for closing steel plant - Winters," Chronicle Herald, 18 October 1967, and Remarks by Mr. C.H. Drury, President, DOSCO Steel Limited, 13 June 1967, Dominion Steel and Coal Company Papers (DOSCO), MG 14.30, box 27, Beaton Institute (BI), Cape Breton University (CBU), Sydney, Cape Breton.

15 See Canadian Dimension 14, no. 4-5 (February-March 1980): 40. On this point generally, see Ernest R. Forbes, "Consolidating Disparity: The Maritimes and the Industrialization of Canada during the Second World War," Acadiensis XV, no. 2 (Spring 1986): 3-27. This trend was noted by the local press at the time: "Little Hope of Expansion or Diversification," Cape Breton Post (Sydney), 3 October 1967, and "Crisis: End Or Beginning?" Cape Breton Post, 16 October 1967.

16 Allan Fenton, "Retrenchment in Coal, Re-Orientation in Steel," Canadian Business (June 1960): 44. The opening of the St. Lawrence Seaway in 1959 complicated matters further for DOSCO; it permitted its Central Canadian counterparts access to cheaper, better-quality resources.

17 "Production and Plant Figures, 1961," MG 19.7 B, United Steelworkers of America fonds (USWA), BI, CBU; Martin Merner to Allan J. MacEachen, 8 June 1967, LPP, MG 26 N4, vol. 45, file 217.31, LAC; "Between the Lines," Cape Breton Post, 23 September 1967. 
city councillor A.E. Nathanson in $1966 .{ }^{18}$ American steel makers in Illinois, Indiana, and Ohio faced similar circumstances about a decade later.

Hamstrung by distance and geology, weakened by particular state policies, and buffeted by intense post-war competitive pressures, DOSCO itself underwent a significant corporate restructuring beginning in 1957, when it was purchased or "raided" - depending on one's view - by A.V. Roe Canada, a subsidiary of the UK-aircraft-making-giant Hawker Siddeley. The Financial Post called it the "largest" corporate merger "in Canadian history." ${ }_{19}$ Attracted primarily by DOSCO's profitability, which had peaked in 1956 and 1957, the new owners envisioned a diversified multi-faceted colossus. Materials and profits derived from an industrial division would bolster the success of a transportation division, which was then dominated by the high-profile supersonic fighter jet, the Avro Arrow, and nourished by successive and highly lucrative government contracts. It was a high-risk, high-gain strategy for the new owners - Hawker Siddeley had no experience in coal mining or steel making - with potentially decisive consequences for Atlantic Canada, where DOSCO remained the single largest employer. ${ }^{20}$ Members of DOSCO's board of directors with direct ties to the region (Frank Sobey and Roy Jodrey) understood this over-reliance well and fought a rearguard action to stop the takeover but to no avail. ${ }^{21}$ Nova Scotia Premier Robert Stanfield shared the same broad concerns and cautioned the new corporate owners that "DOSCO is not just an industry in the ordinary sense; it is the staff of life for many communities in Nova Scotia." ${ }^{22}$ One business writer in the region was far more scathing: "secret plans, subterfuge, misleading statements, rumour-mongering, backroom arm-twisting" had allowed "Montrealers and Torontonians ... to engineer [a] sell-out to the English" - all at Nova Scotia's expense. ${ }^{23}$

From 1957 onward, the new DOSCO followed a two-pronged strategy: a decisive "retrenchment" in mining and a "re-orientation" in steel. In practical terms, this approach meant the closure of collieries in Cape Breton and iron ore mines in Wabana, Newfoundland; little-to-no investment in

18 A.E. Nathanson to Pearson (telegram), 19 Dec 1966, LPP, MC 26 N4, vol. 45, file 217.31, LAC.

19 Cited in Harry Bruce, Frank Sobey: The Man and the Empire (Toronto: MacMillan, 1985), 203.

20 One out of every six paycheques in Nova Scotia came from either big coal or big steel; Sydney Steel's payroll tallied about \$23 million per year. See Fenton, "Retrenchment in Coal, Re-Orientation in Steel," 44 and the Sydney Steel payroll figures are in Hansard, http://0-nsleg-edeposit.gov.ns.ca.legcat.gov.ns.ca/deposit/ HansardDeposit/49-01/19671201.pdf (p. 50).

21 Bruce, Frank Sobey, 203-18.

22 Robert Muir quoting Robert Stanfield, House of Commons Debates, 24th Parliament, 2nd sess., vol. 1, 23 January 1959.

23 Bruce, Frank Sobey, 203, 209. 
new steelmaking technology, research and development, and product lines at the Sydney works; consideration of Holland as a source for crude steel; and significant reduction of employees in the steel city and other industrial communities. ${ }^{24}$ The cancellation of the Avro Arrow project by the federal government, which resulted in massive financial losses for the parent company and thousands of layoffs, accelerated the restructuring process further. Between 1962 and 1966 at least \$75 million was invested in DOSCO's steel operations - nearly all of it directed to the creation of new steel capacity at Contrecouer, Quebec, where potential markets were close. ${ }^{25}$ At the same time, some Sydney-based product lines, such as wire and nail making, were being moved to other DOSCO subsidiaries, a process the steelworkers' union called "stripping" the mill. ${ }^{26}$ "We are confident that we will succeed," C.H. Drury, the head of the company's steel division, remarked publicly, but the United Steelworkers of America was less optimistic: "We must conclude that it is company policy to phase out the Sydney steel plant." ${ }^{27}$ The implications of this strategy were laid bare in 1967.

Sydney celebrated Canada's Centennial in ways that any community in the country, large or small, would have recognized - with concerts, art festivals, and parades as well as the arrival of the Confederation Train, performances by the RCMP musical ride, and a visit from the Queen Mother. The steel city's industrial past and present threaded its way through all of this 1967 hoopla, with DOSCO sponsoring many high-profile events and the community's signature legacy project: a new hockey rink. ${ }^{28}$ However, the youthful, optimistic, future-oriented vibe of the sunny Centennial summer would not linger. On 13 October 1967, the board of directors of Hawker Siddeley Canada unanimously passed a motion to "disengage" from the "operations carried on at the Sydney steel plant" by 30 April 1968. Speaking on behalf of the board, president and chief executive officer T.J. Emmert indicated that the decision was, first and foremost, about profitability: "Neither DOSCO, nor Hawker Siddeley, which owns $77 \%$ of the corporation, can continue to absorb losses of the magnitude now being incurred. In the view of the board, he continued, those losses were

24 Local 1064 of the USWA reported that 1,223 workers were laid off between May and June 1967. See Martin Merner to Allan MacEachen, 8 June 1967, LPP, MC 26 N4, vol. 45, file 217.31, LAC.

25 "Remarks by T.J. Emmert," 16 June 1966, on radio station CJCB, USWA, MC 28, vol. 6, LAC.

26 James A. Nicholson, USWA, to Allan J. McEachen, 19 March 1966, "Sysco-Dosco, 1950s-1970s," \#2009-076, unprocessed, $\mathrm{BI}, \mathrm{CBU}$.

27 Remarks by C.H. Drury, President, DOSCO Steel Limited, 13 June 1967, DOSCO, MC 14.30, box 27, BI, CBU; Eamon Park to William Mahoney, J.C. Nicholson, Gordon Milling, and Ben O'Neil, 28 June 1967, USWA, MC 28, vol. 6, LAC.

28 "Sydney Centennial Program," Bras D'or Collection, \#624, CBU (Library); "Between the Lines," Cape Breton Post, 1 April 1967. 
the by-product of many things, including the end of the global steel shortage that had taken hold during the war years and lasted into the late 1950 s as well as the poor performance of local workers. Most importantly, however, were the insurmountable challenges posed by the location of the steel plant itself. On this point, Emmert was direct: "A number of factors have led to the current position of the steel mill which dates back to 1900 . Its location was originally selected to take advantage of nearby supplies of relatively low-cost iron ore and coal and a deep-water location. The cost advantages disappeared over the years .... It is recognized today that to be successful, a steelmaking facility should be located within, or very close to, a major market area. The Sydney mill's natural market is the Atlantic Provinces but the consumption of steel in that area is far too small to support the Sydney operation. As a result, about $85 \%$ of the mill's output must be sold outside the mill's natural market area."29 In other words, from his vantage point, place, as a geological, political, and economic context for business, was a decisive and fatal liability. ${ }^{30}$ And there was only one reasonable course of action as a result.

The closure announcement was carried on local television and radio stations. People were shocked, shaken, and angry. This was "Black Friday," a phrase that would later warrant its own entry in the Dictionary of Cape Breton English. ${ }^{11}$

\section{Equality}

It came in the form of a press release, with the words "Urgent" in red printed across the top. It was Hawker Siddeley's closure announcement. And it arrived in Premier G.I. Smith's office on 12 October, just a day before it was to be made public. Copies had been sent to Prime Minister Lester Pearson, too, who in turn informed Allan J. MacEachen, the federal minister responsible for Nova Scotia. Smith and MacEachen spoke on the telephone at length after receiving the

29 "Extract from the Minutes of a Meeting of the Board of Directors," 13 October 1967 and press release from J.N. Kelly, Hawker Siddeley Canada, 13 October 1967, RC 100, vol. 39, no.11, NSA; see also C.H. Drury to "All Canadian Steel Consumers," RC 100, vol. 39, no. 2, NSA. Frank Sobey resigned from the DOSCO board as a result of the decision; see Bruce, Frank Sobey, 217.

David Harvey emphasizes the geographical dimension of this question in all of his work. See The Enigma of Capital and the Crises of Capitalism (New York: Oxford University Press, 2010) and The Condition of Postmodernity (Cambridge: Cambridge University Press, 1990), 226-39. The superior mobility of capital over labour is one of the core themes in Cowie, Capital Moves; see chap. 7. It is also the theme of Terry Gibbs and Garry Leech, The Failure of Global Capitalism from Cape Breton to Colombia and Beyond (Sydney: Cape Breton University Press, 2009).

31 "Sydney Steel Plant Will Close by April," Cape Breton Post, 14 October 1967. The earliest reference I have found to "Black Friday" appears in the Cape Breton Highlander, 18 October 1967; the phrase is included in William J. Davey and Richard MacKinnon, eds., Dictionary of Cape Breton English (Toronto: University of Toronto Press, 2016$), 15$. 
grim news and agreed to meet in Sydney as soon as both men could get there. ${ }^{32}$ George Isaac Smith had been premier for only a month, but he was no political greenhorn. As Robert Stanfield's "closest advisor" and "loyal Lieutenant," Smith had been deeply involved in the revitalization of the Conservative Party in the province during the post-Second World War era. Indeed, it was Stanfield who insisted on "Ike" - the former cabinet minister - moving into the premier's office as a pre-condition for his own move into federal politics, which took place in September of 1967 . Shortly after the changeover in Tory leadership, the Sydney steel crisis erupted. It would consume nearly every moment of Smith's political life over the next two years. Some journalists speculated that the stress of the crisis nearly killed him. ${ }^{33}$

Two days after Black Friday, Smith and a special cabinet committee Tom McKeough (Labour), W.S.K. Jones (Trade), Donald MacNeil (Municipal Affairs), and Gerald Doucet (Provincial Secretary) - arrived in Sydney for several days of community meetings. Time was of the essence. Not only had DOSCO set a clear date for the termination of steel production in the city, but it had also determined that the beginning of the end would start by midNovember. No new orders for any product; blasts furnaces blown down one by one; removal of equipment for relocation or sale; and then layoffs, layoffs, layoffs. Smith knew, as did the attendees at the community sessions, that once this process of winding things down was underway the chances of solving this "lengthy, complicated, and difficult" problem were reduced to zero. ${ }^{34}$ Customers that were still on DOSCO's books would, by then, be shopping elsewhere for their steel needs, and managers, engineers, and steelworkers would already be across the causeway looking for work. ${ }^{35}$ Given this scenario, the special cabinet committee recommended that the provincial government seek additional time by agreeing to assume the company's operating loss for a period of four months; then, with that breathing room, it could pursue a

32 A chronology of the crisis and the premier's response is provided in "Text of an address by Premier G.I. Smith at a meeting of the Sydney Rotary Club," 15 October 1968 and "Sysco-Dosco, 1950s-1970s," \#2009-076, unprocessed, BI, CBU; see also "More on Dosco," Information Magazine (January-February 1968): 29-30.

33 First elected to the provincial legislature alongside Stanfield in 1949, Smith served in several senior cabinet positions - including minister of finance - during successive Conservative administrations. "Men like Smith are not entertainers and they cannot be glamorized," Dalton Camp, a key Conservative strategist during the Stanfield years, once observed. "There is no cosmetic in the world which would make Ike Smith a television personality, a charismatic political star, or a clown. He lacks the ego to attempt it and any interest in achieving it." Loved by Tory MLAs and party workers, feared by opposition members in Province House, no one at the time of the steel crisis disputed Smith's level of experience. Beck also writes that the "stress and overwork" left "irreparable harm" on Smith's health. See Beck, Politics of Nova Scotia, 299-318 (esp. 318). The quotation appears in Hansard at http://0-nsleg-edeposit.gov.ns.ca.legcat.gov.ns.ca/deposit/ HansardDeposit/49-01/19671201.pdf (p. 54.)

35 "More on DOSCO," Information Magazine, p. 30 
longer-term negotiated solution. Smith agreed: it was a reasonable first step. A public statement made by Smith and carried on the front page of the Cape Breton Post after these local deliberations called for all levels of government "to do everything possible to ensure the long term continuance of the Sydney steel plant." Privately, Smith was already thinking ahead. Written in the margins of his speaking notes -- alongside reminders to "compliment people" and "be hard with Hawker Siddeley - don't trust them" - was a more substantial commitment: "No philosophic objection to public ownership." ${ }^{36}$

Smith's commitment to public ownership in this context was not without significant and far-reaching financial risk. But the idea itself - that government could and should do something to help - was by then firmly set in Canadian political culture: most people, most of the time, expected government to act. Indeed, by the 1960s, the visible hand of government could be found working at nearly every level of Canadian life - from healthcare and labour relations to post-secondary education, unemployment insurance, old age pensions, and taxation. ${ }^{37}$ A long-time MLA and finance minister, G.I. Smith understood this notion well. The great arch of state intervention was inescapable. Yet resonant, too, was another important post-war political truth. Compared to other Canadian provinces Nova Scotia was very poor - bone-grindingly poor in some places, Smith's home Colchester County included..$^{8}$ These blunt regional economic facts, coupled with rising expectations for government, shaped elements of Nova Scotia's modern political culture in distinctive ways. Angus L. Macdonald beat the drum of regional disparity for two decades, beginning shortly after he was elected in 1933 until his death in office in $1954{ }^{39}$ By taking up this defining question, the long-serving Liberal premier carried forward a political struggle that stretched back to the Confederation debates in the mid-19th century, the "repeal" campaigns of the 188os, and the "Maritime

36 Typed speaking notes, 17 October 1967, RG 100, vol. 39, file 10, NSA.

37 The literature on this subject is massive. See Shirley Tillotson, Give and Take: The Citizen-Taxpayer and the Rise of Canadian Democracy (Vancouver: UBC Press, 2017); Alvin Finkel, Social Policy and Practice in Canada: A History (Waterloo, ON: Wilfrid Laurier University Press, 2006); and E.A. Heaman, A Short History of the State in Canada (Toronto: University of Toronto Press, 2015).

Whereas many regions of the country benefitted economically from the war years and sustained that boost into the 1950 s and 1960s, the opposite was true for Smith's home province. The gap between have and have-not provinces remained wide as the 1940s shaded into the 1950s: the unemployment rate in the Maritimes was consistently higher than the rest of the country, while per capita incomes were about 33 per cent below the national average. See Forbes, "Consolidating Disparity," 3-27; Margaret Conrad, "The 'Atlantic Revolution' of the 1950s," in Beyond Anger and Longing: Community and Development in Atlantic Canada, ed. Berkeley Fleming (Victoria and Fredericton: Centre for Canadian Studies and Acadiensis Press, 1988), 57; Richard Starr, Equal as Citizens: The Tumultuous and Troubled History of a Great Canadian Idea (Halifax: Formac Publishing, 2014), 114-5; and Royal Commission on Canada's Economic Prospects: Final Report (Ottawa: Queen's Printer, 1963 [1957]), 406, Table 19.1. 
Rights" movement that dominated the 1920s. Importantly, his push for better terms for the province rested on a particular view of federalism, government, and rights more in line with these earlier eras: provincial autonomy must be safeguarded and investments in roads and schools marked the outer limits of state intervention.

Like Angus L.'s lengthy tenure in office, Robert Stanfield's time in Province House was similarly shaped by the political economy of regional inequality. Yet unlike his Liberal forerunner, Stanfield addressed these issues by widening the scope of public policy to include the economy. Without a solid, diversified base of labour-intensive, secondary manufacturing, he maintained, the advances of the post-war world would continue to pass the province by. This was the progressive side of the premier's conservatism. The influence of the post-war era's growing confidence in government is not hard to see; nor is it difficult to spot the popularity of "development" as an idea - and its underlying faith in the ability of science, technology, and expertise to bring about progress and usher in the modern..$^{40}$ This approach to the province's woes found tangible expression in the creation of Industrial Estates Limited, a provincially owned Crown corporation dedicated to economic development. Announced during the election campaign in 1956 and up and running a year later, IEL built industrial parks, leased factories, offered business loans, and bought mortgage bonds - all of it designed to make Nova Scotia modern. ${ }^{41}$ And, at the time, it appeared to be working. By the mid-1960s more than 50 companies had been lured eastward, including corporate heavyweights National Sea and Michelin Tire. "Nova Scotia Moves into the Mainstream," declared a headline in the Financial Times of London in $1965 .{ }^{42}$ As Stanfield's right-hand man and provincial treasurer, Ike Smith was knee deep in all of this.

Regional disparity, economic development, and public policy preoccupied other political actors too - thickening the political discourse on these questions considerably. Provincial premiers from Atlantic Canada, including

40 Development ideas in the regional context of Cape Breton are addressed in William Langford, "Helping People Help Themselves: Democracy, Development, and the Clobal Politics of Poverty in Canada, 1964-1979" (PhD thesis, history, Queen's University, 2017).

41 This summary is drawn largely from Geoffrey Stevens, Stanfield (Toronto: McClelland and Stewart, 1973), 106-40. See also Peter Clancy, "Concerted Action on the Periphery? Voluntary Economic Planning in 'The New Nova Scotia'," Acadiensis XXVI, no. 2 (Spring 1997): 3-30; Dimitry Anastakis, "Building a 'New Nova Scotia': State Intervention, The Auto Industry and the Case of Volvo in Halifax, 1963-98," Acadiensis XXXIV, no. 1 (Autumn 2004): 3-30; Margaret Conrad, "The 1950s: The Decade of Development," in Atlantic Provinces in Confederation, ed. Ernie Forbes and Del Muise (Toronto: University of Toronto Press, 1993), 382-420; and James P. Bickerton, Nova Scotia, Ottawa, and the Politics of Regional Development (Toronto: University of Toronto Press, 1990).

42 Ralph Surette, "A Lion of Nova Scotian Economic Development," 23 August 2010, rabble.ca/columnists/2010/08/lionnova-scotia-economic-development. 
Newfoundland, found some common ground with the formation of the Atlantic Provinces Economic Council in 1954. Populated by the business elites, the council sought to advance a regional economic agenda by sponsoring research, holding conferences, publishing op-eds, lobbying federal politicians, and acting as a conduit for the "exchange of ideas between leading men in economic, government, and professional fields." ${ }^{43}$ Universities in the region amplified the discussion further. ${ }^{44}$ There were also federal investigations like the Royal Commission on Canada's Economic Prospects, which concluded its work in $1957 .{ }^{45}$ And there were significant federal policy developments aimed at regional questions too, including the start of equalization payments (1957) under the Conservative government of John Diefenbaker and then later, under Liberal administrations, the creation of the Atlantic Development Board (1962), the Area Development Agency (1963), the Agriculture and Rural Development Act (1966), and the Cape Breton Development Corporation (1966).

That final initiative - DEVCO - owed its life in part to Allan J. MacEachen, who by then anchored the Grits' "liberal wing" and had "proven himself a progressive" at the highest levels of political decision-making. ${ }^{46} \mathrm{~A}$ coal miner's son from Inverness County, MacEachen's path to progressivism included exposure to the co-operative movement while an undergraduate at St. Francis Xavier University in the early 1940s, advanced study in economics and sociology at the University of Toronto and Massachusetts Institute of Technology, and a stint as a faculty member at his Antigonish-based alma mater. In that role he was active in the "People's School," an experiment in adult education undertaken by the university's high-profile Extension Department. "Political freedom may become meaningless to many people unless the main problems in the economic field are successfully resolved," MacEachen once

43 Nelson Mann, "Atlantic Provinces Economic Council," Dalhousie Review 35, no. 4 (Winter 1956): 317.

44 The Atlantic Provinces Research Board at University of New Brunswick (Fredericton), the Institute of Public Affairs at Dalhousie University (Halifax), and the Extension Department at St. Francis Xavier University and Xavier Junior College (Antigonish and Sydney) all studied these broad questions, sometimes in conjunction with a federal or provincial agency or APEC or both. One example is Wood and Verge, Study of the Problems of Certain Cape Breton Communities.

45 Concerned primarily with the overall development of the Canadian economy, the influence of American investment north of the border, and the possibilities of government action, the eloquent final report of the Royal Commission on Canada's Economic Prospects also examined the country's different regions - some of which were "not sharing fully in the economic progress of the country as a whole" (14-15). Regional tension turns up in many parts of the report. See, for example, Royal Commission on Canada's Economic Prospects, 1, 8, 9, 14-15, 48, 404-19. This was not the first time, of course, that the regional economy had been assessed: between 1926 and 1960, 13 other royal commissions had considered similar questions. See "Royal Commission Reports and Related Action: A Review of Recommendations and Policy on Economic Issues in the Maritime Provinces, 1926-1960," Institute for Public Affairs, Publication \#19, Dalhousie University, 1960. 
observed in a People's School radio broadcast. ${ }^{47}$ Elected to Parliament in 1953, the future cabinet minister's broad outlook meshed easily with some of the dominant political assumptions of the era: by the time of the steel crisis, regional equality was widely viewed as a positive right requiring intensive state action for its full realization.

Furious, multi-front negotiations between the provincial government, Ottawa, and DOSCO started immediately after the closure announcement and lasted well into early 1968 . Telegrams, letters, memos, and reports proliferated; so, too, did telephone calls, press conferences, and formal negotiations in Halifax, Toronto, Montreal, and on Parliament Hill. After first considering then rejecting the idea of expropriation, Premier Smith and his high-level cabinet committee advanced the idea that the newly formed Cape Breton Development Corporation, which was mandated to rationalize the island's coal industry, should assume responsibility for the Sydney steel works too. ${ }^{48}$ The unfolding collapse was so severe - in their judgement - that the province was prepared to cede control of its industrial economy to a federal Crown corporation. This idea was not new. Variations of it had, in fact, circulated among Ottawa mandarins when the legislative framework for DEVCO was first created. The director of St. Francis Xavier University's Extension Department had put the notion directly to the prime minister at the time: "panic" and "despair" threatens the entire island, he argued, and "since [the steel] industry should be an essential element in the industrial development of Cape Breton, it would seem quite fitting that its future should be of concern to the corporation charged with planning the future of the Island."49

Although MacEachen had proposed the same idea publicly in the early days of the steel crisis, it found no purchase among his cabinet colleagues or the prime minister. Coal had been shaped decisively by decades of federal policy so the argument went, thus Ottawa was obligated to mitigate the impact of its decline - in this instance, through DEVCO. The same could not be said for steel. Moreover, the federal government was already massively involved in the stabilization and reconstruction of the regional economy - with existing

\footnotetext{
47 Excellent primary sources related to the Extension Department and People's School in late 1940s and early 1950s, including lists of subjects addressed in radio broadcasts, are contained in the appendices of Sister Saint Francis Miriam's "The Historical Background of the People's School" (BA honours essay, St. Francis Xavier University, 1955). This essay is located in the book collection at the Beaton Institute, and the quotation is on p. 14.

48 "Confidential Memorandum for the Prime Minister, Dosco's Sydney Steel Plant," 16 October 1967, LPP, MG 26 N4, vol. 45, file 217.31, LAC.

49 J.N. MacNeil to Lester Pearson, 3 January 1967, LPP, MG 26 N4, vol. 45, file 217.31, LAC. What form this inclusion would take is not altogether clear from this letter; MacNeil wants it included, but not purchased in the same way as coal.
} 
and projected commitments through various agencies exceeding \$75 million dollars in Cape Breton by 1971. "The immediate reaction of federal ministers and officials ... was that it was no use prolonging the agony and that we must, at all costs, avoid taking over the plant," read one report prepared for Prime Minister Pearson. In line with this rationale, Ottawa sought to ensure provincial responsibility for the steel crisis and at first proposed a more limited solution: assist any displaced steelworkers, pay for a study of Sydney steel, enforce Canadian anti-dumping laws, and encourage Quebec's staterun steelmaker to buy its basic steel from the east coast. Fiscally modest, the proposal was also viewed as politically realistic. "A judicious dose of economic nationalism was needed to safeguard and expand our automobile production," one influential civil servant observed. But that was not the case with DOSCO. The prime minister agreed: "If this were a U.S. subsidiary, there would be enormous political pressure being generated." ${ }^{50}$ Pressure of a different sort would come later.

As October gave way to early November, the province's bargaining position softened. Perhaps Allan J. MacEachen had a hand in this shift. G.I. Smith and the province's special cabinet committee abandoned the notion that Ottawa should nationalize the plant and argued, instead, for federal assistance for steel until the Cape Breton Development Corporation had successfully diversified the island's economy. That position was then subsequently revised: would Ottawa cover DOSCO's operating losses until the end of April 1968? That way the plant would operate as a "going concern" - instead of being wound down - and the search for a long-term solution could begin in earnest. Despite the warnings of Privy Council officials and the conclusions of a consultants' report - "Sydney steel is not and cannot be a viable economic operation" ${ }_{51}$ the prime minister, in time, agreed with his provincial counterpart. Ottawa would assist the province financially with DOSCO on a short-term basis, but it would not take a direct ownership stake in the plant itself. More focused discussions between both levels of government on the time frame and funding formula for such a contribution ensued.52 Early estimates placed Ottawa's direct involvement at roughly $\$ 4$ million. While Premier Smith still held out hope for more federal assistance, through a forgivable loan or a reduction in the

50 "Confidential Memorandum for the Prime Minister, Dosco's Sydney Steel Plant," 16 October 1967, LPP, MG 26 N4, vol. 45, file 217.31, LAC. Pearson is quoted in the cover letter; O.C. Stoner's comment appears on p. 4 of the memo.

51 O.C. Stoner, "Report of Consultants to Nova Scotia Government on the Sydney Steel Plant," 13 November 1967, LPP, MC 26 N4, vol. 45, file 217.31, LAC.

52 O.C. Stoner to Prime Minister Pearson, 27 October 1967 and Pearson to G.I. Smith, 8 November 1967, LPP, MC 26 N4, vol. 45, file 217.31, LAC. 
provincial government's financial obligations for the Cape Breton Development Corporation, provincial bureaucrats began drafting new legislation to facilitate Nova Scotia's entry into the steel business.

For its part, DOSCO held fast to its commitment to "disengage" from steelmaking in Sydney. It refused to consider any scheme that might extend its financial commitments beyond the announced closure date. When asked to participate in face-to-face discussions in the steel city, T.J. Emmert suggested that community and government officials could visit him in Toronto; his number - the senior executive said - was in the telephone book. An invitation from the Nova Scotia legislature to appear before a standing committee was similarly rebuffed..$^{53}$ On the corporate side, therefore, negotiations coalesced quickly around three basic questions, all of which underscored DOSCO's commitment to terminate its Sydney-based operation: what was the present value of the company, how much was it losing each month, and who should make these financial determinations for the purposes of a potential sale to the province?54 Those answers would come later. In late October and early November, members of the province's special cabinet committee on steel McKeough and Jones - undertook several lengthy sessions with the company in Toronto. At the same time, Ottawa directed its own back channel pressure toward the company, citing its many interests across the country in many fields of federal policy. The broad parameters of a deal with DOSCO were in place by 21 November. Meanwhile, resistance in the steel city continued to build.

If "place" remained a liability for the corporation, the same cannot be said for the provincial or federal governments. Despite their policy differences, both could accept the notion that it was a legitimate basis upon which to debate the question of equality. Put another way, few at the highest levels of government decision-making suggested letting the corporation, the free market, and a particular definition of place carry the day completely. "The critical fact is that the closure of the DOSCO steelworks is a symptom of a seriously deteriorating economic situation in Nova Scotia," observed Maurice Sauvé, the federal minister responsible for rural economic development. "At the policy level, [however,] the collapse of a provincial economy cannot be accepted." 55

53 "Confidential Memorandum for the Prime Minister, Dosco's Sydney Steel Plant," 16 October 1967, LPP, MC 26 N4, vol. 45, file 217.31, LAC. The text of DOSCO's response to the province's invitation is found at http://0-nsleg-edeposit.gov. ns.ca.legcat.gov.ns.ca/deposit/HansardDeposit/49-01/19671201.pdf (p. 21). 


\section{Identity}

The unwinding of steel was evident long before DOSCO's announcement. A report prepared jointly by the United Steelworkers of America and St. Francis Xavier's Extension Department in 1966 warned of impending disaster: "The fear amongst the people of Cape Breton is not only that DOSCO intends to reduce the Sydney steel plant to raw steel producer over the next decade, but that eventually it will buy its raw steel also from Sidbec/Contrecoeur, leaving Cape Bretoners with nothing but ashes in their mouths and carbon dioxide in their lungs. ${ }^{36}$ Similar sentiments poured forth in letters mailed to Prime Minister Pearson, key Liberal cabinet ministers, and opposition members in 1965, 1966, and early 1967. One telegram, signed by 5,300 "people of Cape Breton," warned of the "grim prospects" and "hardships" on the horizon.57

Yet this awareness did little to cushion the impact of the closure announcement when it finally came. "I still can't believe it's going to happen. I've lived in Sydney all my life and I certainly wouldn't want to leave here," observed steelworker Ray Drohan. "When the blow comes all at once, everybody takes it on the chin," echoed fellow union member Bennie DeLorenzo. "When a man has children and a house to pay for, news like this is hard to take. ${ }^{58}$ In the days and weeks that followed the closure decision, people deployed a range of metaphors to assign meaning to the company's actions and their impact on the city and island. It was a "staggering blow," an "enemy attack," a "bombshell" that sent "shockwaves throughout industrial Cape Breton," produced "a state of emergency," and left people "shocked" and "horrified." It was a "double cross," a "robbery," a "rape." 59 There is violence in each of these phrases: people - it seemed - felt violated in an intimate way by DOSCO's actions, whether they worked at the plant or not. There is something physical being conveyed here as well: attacks, assaults, and rapes are exercises in power directed at human bodies. Other, less graphic metaphors made the same corporeal point, blurring the line between industry and individual further, albeit in a different way. To some, the steel plant was the "backbone," "heart," and "mother" of the city. ${ }^{60}$ It was, in other words, an embodied presence that

\footnotetext{
"A Submission to the Atlantic Development Board," 28 March 1966, MG 19.7, A1, 78.82.552, BI, CBU.

Telegram from the "people of Cape Breton," 25 June 1967, LPP, MG 26 N4, vol. 45, file 217.31, LAC.

"Steelworkers ... Shocked," Cape Breton Post, 14 October 1967.

Cape Breton Post: "10 Years of Neglect," "Bombshell Hits," "Industry was Robbed," and "Staggering Blow" (all on 14 October 1967) as well as "Plant Nationalization," 17 October 1967 and "Proclamation Endorsed," 16 November 1967; see also Atlantic Mirror: The Voice of the Maritime Writer, no. 4 (Winter 1968), cover.

60 Gregory MacChesney to Pearson, November 1967 ("heart"); Joan Sheppard to Pearson, 6 November 1967 ("backbone"
and "heart"); Louise March to Pearson, November 1967 ("mother"): D.H. Fullerton, "Hope for Cape Breton," ("heart"), and "heart"); Louise March to Pearson,
LPP, MG 26 N4, vol. 46, file 217.31, LAC.
} 
could not be excised easily. Cape Bretoners, one journalist wrote, were indeed "a breed a part."61

Trying to comprehend the closure decision was accompanied by a simultaneous urge to resist it. From this angle of vision, "place" was understood not as a liability but as a resource - a political imaginary that could be mobilized to achieve greater regional equality. Anchoring this emerging worldview was a multilayered sense of history that for many was marked off by the years they spent in the plant itself. "Between my brothers and myself who have worked for DOSCO we have more than 120 years of service," observed Nelson Muise, who was a 43-year-old father of 9 at the time of the crisis. "My son is attending university now and I hope he will never have to work for a company such as my father, my brothers and I have been shackled to for generations now. My wife and I are raising our children here and my roots are deep enough that I feel I have a right to something DOSCO and Hawker Siddeley have denied me ... the security of a job in a stable industry." ${ }^{62}$ In this narrative, Nelson's recollection of his labouring life is tied directly to an awareness of being a husband, father, breadwinner, and a man. Fulfilling these roles, he is suggesting, provides the moral basis for his resistance to the plant closure: somebody owes him something. Nelson's wife, Helen, agreed: “My husband built our home with his own hands 16 years ago. We love it. It would break our hearts to sell it, even if we could, which I doubt, now that so many people will be leaving the area." ${ }^{6}$

Other men started from the same point - talking about their time on the job - but stressed other forms of sacrifice, either to their class or country. Some had relatives who had participated in the brutal 1923 steel strike, while others were directly involved in the pivotal 1947 confrontation, which was fought in tandem with steelworkers in Ontario. References to the Second World War were put forth as well: war-time service, either on the home front or battle front, illustrated steelworkers' willingness to shoulder a heavy, individual burden for the benefit of the wider common good. Now was the time - they were saying - to return the favour. ${ }^{64}$ Historical biographies of personal sacrifice

\footnotetext{
61 Arthur Mclvor, "Deindustrialization Embodied: Work, Health, and Disability in the United Kingdom since the MidTwentieth Century," in The Deindustrialized World: Confronting Ruination in Postindustrial Places, ed. Steven High, Lachlan MacKinnon, and Andrew Perchard (Vancouver: UBC Press, 2017), 25-45; "A Breed A Part," Cape Breton Post, 4 November 1967.

62 "Dosco's Legacy of Bitterness," Information Magazine (December 1967), 13; "Sysco-Dosco, 1950s-1970s," \#2009-076, unprocessed, BI, CBU.

63 "Like a Nagging Pain," Cape Breton Post, 18 October 1967.

64 Themes of sacrifice come through in "The March of Concern," "The People Speak," and "Dosco's Legacy of Bitterness," Information Magazine (December 1967), 4, 9, 13; "Sysco-Dosco, 1950s-1970s," \#2009-076 unprocessed, BI, CBU.
} 
were embroidered by wider assessments of the island's past. For the Cape Breton Highlander, an independent weekly newspaper, Cape Breton's story was largely one of corporate exploitation and squandered potential: "We are the sum of what has transpired in the past." ${ }^{\prime 65}$ Others agreed - and took the long, historical view to substantiate their contemporary obdurance. "Colonial plunderers" read a protest sign at the Parade of Concern, referring to DOSCO. It was as bad as the "expulsion of the Acadians," remarked Reverend George Topshee, associate director of the local office of St. Francis Xavier's Extension Department. ${ }^{66}$

That the steel crisis took place in the fall of 1967 inspired many Cape Bretoners to re-evaluate the historical significance of Confederation itself. The gap between the historic promise of a new nation and the contemporary reality of industrial ruin was stark and could not be overlooked. The point was made implicitly, when young, placard-carrying protestors stood in front of DOSCO's \#1 gate the day after Black Friday - their grim faces standing in stark contrast to the upbeat, Centennial-year messages also adorning the plant's entrance. The point was made symbolically when local businessman and coin collector Jack Stephens minted a ceremonial Centennial year coin: one side of the coin featured the stylized, Centennial year maple leaf, while the other side revealed text commemorating Black Friday: "The day Hawker Siddeley announced it would close the Sydney Steel Works in six months. Let our watchword be TEANN-GHLAC!! HOLD FAST!!” About 100 of the coins were made, and one found its way to the prime minister. ${ }^{67}$ The point was also made directly. Beginning in 1960, St. Francis Xavier Extension Department member Andy Hogan presented a passionate and consistent defense of the island's dominant industries - coal and steel - and the workers and families who sustained them: "If the Fathers of Confederation had been governed primarily by economic reasons and 'free enterprise' reasoning there would have been no confederation. ${ }^{\prime 68}$ Perceptive and prescient, Hogan made the same arguments in the heat of the steel crisis at a teach-in at University of King's College in Halifax. "They have a very deep sense of grievance that the Confederation

Wartime references appear in children's letters too; see, for instance, Judy Mclntyre and Ann Lorrain MacNeil to Pearson, 6 November 1967, LPP, MG 26-N4, vol. 46, file 217.31, LAC. 
promise ... has been badly broken," the Toronto Star observed. "One hundred years of injustice is rapidly being adopted as the new . . chant." ${ }^{\prime 69}$

The articulation of an island identity was especially vivid among young people, who played an important role in creating and sustaining the local response to the steel crisis. In public and private, young people interpreted the end of steel in a variety of different, yet overlapping ways: it was a crisis of fathers and families; a battle against a foreign corporation, hostile Central Canadian media, and the raw deal of Confederation; and a threat an existential threat - to their island home.70 "I was born here, I'm a Cape Bretoner, so was my father and his father before him. I learned to love this island, the hills and vales, the spray from the Atlantic Ocean," observed Rachel DeLeskie, a student at Holy Angels High School in Sydney's North End. "I love Nova Scotia, but I like Cape Breton even better," echoed Colleen MacCormick from her desk at Cornwallis School, located across town in the city's Ashby neighbourhood. "All of the scenery is beautiful, rolling hills, green grass and forests, and lovely Indian summers, reds, greens, browns, and yellows." ${ }^{71}$ In the midst of an unfolding urban, industrial crisis, Rachel and Colleen's words, which pop with pastoral colours and visions of the sublime, are especially vivid: the young women were deeply attached to the island, derived part of their personal identities from its landscape, and did not want to leave.

This sense of rootedness was common among young people. It was multifaceted too. Place of birth mattered. "I was born here," some kids pointed out, "and so was my father and grandfather." ${ }^{2}$ Simple and heartfelt, such observations fused personal history, family genealogy, and place together into a powerful whole and stretched it over a time frame and scale of being that was intimately understood. They were narrating their own lives. Other quotidian experiences lent depth and strength to young people's sense of belonging. Their homes, schools, and places of play; work lives of their fathers and grandfathers; networks of peers; contributions to the community; "stories about the hardships encountered by our people": it all added up and made Cape Breton personally and collectively meaningful. "Nobody wants to leave here. It

69 "Teach-In Sydney Steel Crisis - King's University," PAM 1185, BI, CBU; "Cape Breton can be a winner too," Toronto Star, 29 November 1967.

70 I have addressed these issues in detail in Parnaby, "Growing up Even More Uncertain: Children and Youth Confront Industrial Ruin in Sydney, Nova Scotia, 1967," in High, MacKinnon, and Perchard, Deindustrialized World, 87-110.

71 Rachel DeLeskie to Pearson, 8 November 1967 and Colleen MacCormick to Pearson, 8 November 1967, LPP, MC 26N4, vol. 46, file 217.31, LAC.

72 References to birthplace and family links can be found in letters from Luca DiFlavio, Nora MacNeil, Terrance Brophy, Rachel DeLeskie, and Patricia Drohan, LPP, MC 26-N4, vol. 46, file 217.31, LAC. 
might not be as beautiful as New York or some other big city," one student at Holy Redeemer High School for Girls in Whitney Pier remarked, "but its part of us and we're satisfied with it."73

Deep, as well, were young people's attachments to places outside of Cape Breton County, where steel and coal reigned. Urban and rural, modern and antimodern could be held together in a single, youthful, angle of vision. Many steel families traced their origins to rural Cape Breton and Newfoundland and returned there to see family; fishing, hunting, and swimming were popular, providing relief from urban life. ${ }^{74}$ The (diminishing) use of Gaelic or French in Sydney, the presence of small "baby barns" alongside single-family dwellings, and the popularity of salt fish and beef for dinner looped city and country together in subtle but ongoing ways. For young people, the island was a coherently understood whole. And it was endangered. Stalking this collective sense of belonging was the likelihood of having to leave the island altogether, a form of exile from the "homeland" they had come to love.75 Emptied of its people, the kids reasoned, Cape Breton would "fall to pieces," "go back to the primitive ways of life," and possibly "vanish from the map" altogether leaving "disease," "tramps," and "ghosts" behind. ${ }^{76}$ The Cape Breton Post was of the same opinion. One editorial cartoon featured two top-hat-clad Hawker Siddeley executives turning their backs on the island, leaving the entire land mass - not just the industrial zones - to sink beneath the surface of the ocean. ${ }^{77}$

This sense of island identity was extended outward by local print and broadcast media. Established in 1929, CJCB radio was especially influential. The radio station, with its strong signal (10,0oo watts), local content, and dominant market share (reported to be 92 per cent at its peak), had over its long history given rise to a shared sense of the island's distinctiveness, which was now under threat from DOSCO's decision. ${ }^{78}$ In the context of the steel

73 Donna St. John to Pearson, 8 November 1967, LPP, MG 26-N4, vol. 46, file 217.31, LAC.

74 M. Cook, "Going Down the Road: Rural Cape Breton Migration to the Sydney Steel Plant, 1899-1920," Nashwaak Review 24/25, no. 1 (Summer/Fall 2010): 258-375; Ron Crawley, "Off to Sydney: Newfoundlanders Emigrate to Industrial Cape Breton, 1890-1914," Acadiensis XVII, no. 2 (Spring 1988): 27-51.

75 Arlene Corbett to Pearson, 6 November 1967 and Darlene MacDonald, 3 November 1967, LPP, MG 26-N4, vol. 46, file 217.31, LAC

76 Helen Forbial to Pearson, 6 November 1967; Joan Sheppard to Pearson, 6 November 1967; and Sheldon Braithwaite to Pearson, 5 November 1967, LPP, MG 26-N4, vol. 46, file 217.31, LAC. This material is drawn from Parnaby, "Growing up Even More Uncertain," in High, MacKinnon, and Perchard, Deindustrialized World, 87-110.

77 "Down the Drain," Cape Breton Post, 16 October 1967.

78 My analysis is based on Wendy Bergfeldt, "Tuned In: Radio, Ritual, and Resistance, Cape Breton's Traditional Music, 1973-1998" (MA in Interdisciplinary Studies, Athabasca University, 2015); Ian Brodie, "Local Radio and Vernacular Parody: 'Casey Jones,' 'Dishpan Parade,' and Cape Breton Song" (unpublished essay, presented to the Old Sydney Society, April 2017); and Robert J. Morgan, Rise Again! The Story of Cape Breton Island, from 1900 to Today (Wreck Cove, NS: Breton Books, 2009), 185-200. 
crisis, the radio station helped to draw urban and rural Cape Bretoners together in a community of interest. Throughout October and November, many of the pivotal events of the steel crisis were carried live, including the original DOSCO announcement, the visit of the provincial cabinet, and the Parade of Concern. Images from the time show CJCB's microphone sitting prominently on the lectern at the community rally, where Premier G.I. Smith, MP Allan J. MacEachen, and event organizer and activist priest Father William Roach spoke. Steel stories featured prominently in hourly newscasts, while panel discussions and special programing - "We interrupt this program to bring you a special news bulletin" - rounded out the weeks and weeks of intensive coverage. Fifty years after the events, many individuals still recall the radio coverage with great clarity. ${ }^{79}$

A daily call-in show, AM Talkback, was particularly engaged in the steel crisis. One of the program's occasional hosts was Whitney Pier-born actorturned-journalist Bill Jessome, who also anchored the evening news on CJCB-TV. He had strong ties to the community group organizing the Parade of Concern. In the weeks and days running up to the community-wide demonstration, Jessome used his on-air platform to interview sympathetic guests - like Sandy Campbell, editor of the Cape Breton Highlander - and assess a wide range of issues, from worries about parking along the parade route to whether or not Cape Breton might do better as a US state. In response to dozens of listener phone calls, Jessome mounted a congenial, occasionally critical, defense of the industry, city, and island. He did not shy away from difficult questions: "Is the province capable at this present time of meeting this tremendous financial obligation? Where is all this money coming from?" Nor did he hide his clear sense that island-wide unity was critical if Cape Breton itself was to survive. The "future," he said often on AM Talkback in his rich, masculine, "newsman" voice, depended on people's willingness to take action. ${ }^{80}$ As the surviving audiotapes reveal, not a single caller to Jessome's show opposed his perspective on this particular issue.

By the time M.A. MacLellan, the president of St. Francis Xavier University, penned his letter to Prime Minister Pearson calling for a "thunderous 'no'!" to corporate "irresponsibility" and the "inexorable dictate of economics," the contours and characteristics of the "fighting Cape Bretoner" had come fully

79 The recollections of an audience member at a public talk I gave for the Old Sydney Society in Sydney in in 2016 are suggestive; see https://www.youtube.com/watch?v=2BnQLV_kIT4 (at 1:16:15).

80 Bill Jessome, CJCB Talkback: "Steel Crisis 1967," audio recording, T-81, BI, CBU. 
into public view. It was palpably in the world. There was broad acceptance of the steel plant's embodied presence; pooled notions of personal and collective sacrifice; a common history of exploitation and thwarted potential; a shared understanding of external enemies and political goals; a deep, binding attachment to place; and an apocalyptic vision of the future - complete with visions of ghosts and ghost towns. Under the heavy pressures of economic crisis, pre-existing or newly discovered affinities to the island's history, culture, and landscape were brought together in ways that were morally and politically powerful for people - young and old, urban and rural, steelworkers and others. Conceived of in this way, "place" was not understood as a liability but as an embodied expression or articulation of "we" that brought with it the likelihood of resistance.$^{81}$ Longstanding divisions within industrial Cape Breton did not, of course, disappear; many reasserted themselves shortly after the crisis. ${ }^{82}$ Yet they were temporarily eclipsed by a broad, place-based sense of identification that would tumble forward into future generations. As the Cape Breton Highlander observed: "The last battle has begun. Cape Breton is fighting for its life. Does everybody realize that?" ${ }^{3}$

Indeed, they had. On 19 November 1967, a large crowd gathered near the Sydney steel plant. Some came from the neighbouring towns of Donkin, Glace Bay, and New Waterford; others had made the drive from further afield, from places such as Inverness, Big Pond, and North Sydney. The majority came from the steel city itself. As 1:30 approached, the large crowd had become a parade, which grew larger and larger as it snaked its way from the steel plant eastward along Prince Street, past Ashby junction, to a nearby harness-racing track - its large grass oval and open grandstand a perfect location for a mass rally, a parade of concern. ${ }^{84}$ By the time the final few participants had passed the track's stables and entered the venue, about 20,000 people - "students, housewives, steelworkers, coal miners, fishermen, doctors, clergymen, lawyers, members of the business community, teachers, Indians, and Roman Catholic

81 On this specific point, see David Snow, "Collective Identity and Expressive Forms," CSD Working Papers (2001), 3, https://escholarship.org/uc/item/2zn1t7bj. My general sense of this question has been framed by Benedict Anderson, Imagined Communities: Reflections on the Origins and Spread of Nationalism (London: Verso 1991); R.D. Benford and D.A. Snow, "Framing Processes and Social Movements: An Overview and Assessment," Annual Review of Sociology 26 (2000): 611-39; Gerald Friesen, Citizens and Nations: An Essay on History, Communication, and Canada (Toronto: University of Toronto Press, 2000); Paul Litt, Trudeaumania (Vancouver: UBC Press, 2016); and Gerard Bouchard, Social Myths and Collective Imaginaries (Toronto: University of Toronto Press, 2017).

See, for example, Elizabeth Beaton, "An African-American Community in Cape Breton, 1901-1904," Acadiensis XXIV, no. 2 (Spring 1995): 65-97 and Martha Walls, "The Disposition of the Ladies: Mi'kmaw Women and the Removal of the King's Road Reserve, Sydney, Nova Scotia," Journal of Canadian Studies/Revue d'études canadiennes 50, no. 3 (Fall 2016): 538-65.

83 Editorial, "To the Barricades," Cape Breton Highlander (18 October 1967) 
nuns" as well as "Boy Scouts, Girl Guides, Little Leaguers, Rotary Hockey players" - were already there, enjoying another round of "Let's Save Our Industry" by steelworker and musician Charlie MacKinnon. ${ }^{85}$ Protest signs were everywhere - chastising the company, vouching for the work ethic of Cape Bretoners, highlighting the false promise of Confederation. The parade was supposed to show the "breadth and depth of our concern" about the "whole economic situation," remarked Neil Donovan, a local psychiatrist and occasional CJCB guest. And in doing so, it was designed to pose an important question: does the "idea of Canada" include Cape Breton? Several speeches rounded out the rally, including a powerful call by Father Roach, one of the event's organizers, for the government to end the crisis and for Cape Bretoners to remain firm in their resolve to defend the island's most important industry: "Government must commit itself clearly and positively to the principle that the welfare of the people - of all of the people in all the areas of Canada - is paramount." ${ }^{16}$ Roach would later win the "Citizen of the Year Award" from the Rotary Club for his actions during the steel crisis. Both Smith and MacEachen, who were part of the platform party, spoke too; they hinted that support from government was in the offing.

It came on December 1, when Premier Smith introduced legislation to save Sydney steel. "The Bill has the effect of putting the Province into the steel business - at least on a temporary basis - and will place a substantial burden upon the taxpayers of Nova Scotia," Smith said. "The cost is great. But the cost of any alternative would be even greater. Indeed, it seemed to the Government, that closing the plant suddenly ... would result in such a social and economic cost, that it could not be accepted, if there was any possible way to avoid it." ${ }^{\text {7 }}$ The initial, upfront cost for Halifax was estimated to be close to $\$ 30$ million dollars - about the same cost to the provincial treasury as a single year of medicare. The final terms of the federal government's role were settled in early 1968 - assistance with a feasibility study and covering the plant's operating losses for a four-month period. Smith did not hide his disappointment with Ottawa's final position. "I am sure it will come to you as no surprise that the government of Nova Scotia is not able to regard your government's decision with much satisfaction," he told Prime Minister Pearson. "It seems to us that

85 Ronald Caplan, ed., Views from the Steel Plant (Wreck Cove, NS: Breton Books, 2005), 171-88; picture of MacKinnon, Cape Breton Post, 17 January 1968. In Rise Again! (132), Morgan puts the attendance figure at 35,000, but I cannot find any source from 1967 that suggests such a high tally; police and media reports at that time estimated that between 18,000 to 25,000 people were there. 
the decision falls for short of discharging the very heavy national responsibility involved in this whole situation." ${ }^{\text {88 }}$ Despite such deep misgivings, Sydney steel had been "saved."

\section{Conclusion}

The literature on de-industrialization is large, growing, and multifaceted. ${ }^{89}$ Over the past 30 years, scholars have sought to understand the causes and consequences of this phenomenon from a wide range of perspectives historical, political, sociological, psychological, and ecological. Of particular importance to this article is a question that has appeared in the literature from its inception: why have some communities successfully resisted the collapse of heavy industry while others have not?90

Writing in the North American context, Steven High has argued that Canadian workers in southwestern Ontario slowed the pace of deindustrialization by deploying the power of Canadian nationalism. In doing so, they strengthened union ranks, created durable community partnerships, and thus mounted an effective resistance - results that American workers, who relied on a more limited discourse of "community," were unable to attain..$^{91}$ There is a compelling directness to this argument. It does not, however, capture what happened in Sydney, Cape Breton, in 1967. There, as this article suggests, the shared viewpoint that formed among workers, community leaders, politicians, and others was held together by a sense of regional fairness, not impending American corporate dominance. Any local expressions of Canadian nationalism, which did turn up in speeches, press coverage, and conversations, were either ironic in style - "Happy Centennial Year!" - or served to shore up the community's dominant, overriding sentiment: the island itself was under siege and must be defended.

Had Hawker Siddeley been an American corporation, it is possible that the community's response would have displayed a more fully articulated

88 Smith to Pearson, 6 February 1968, RG 100, vol. 39, file 2, NSA.

89 See, for example, High, MacKinnon, and Perchard, Deindustrialized World; Tim Strangleman and James Rhodes, "The 'New' Sociology of Deindustrialization? Understanding Industrial Change," Sociological Compass 8, no. 4 (April 2014): 411-21; Steven High, "'The Wounds of Class': A Historiographical Reflection on the Study of Deindustrialization, 1973-2013," History Compass 11, no. 11 (November 2013): 994-1007; Parnaby, "Life Among the Ruins"; and Lachlan MacKinnon, "Deindustrialization on the Periphery: An Oral History of Sydney Steel, 1945-2001" (PhD, history, Concordia University, 2016).

90 On this question see, for example, Staughton Lynd, The Fight Against Shutdowns: Youngstown's Steel Mill Closings (San Pedro, CA: Singlejack Books, 1982); High, Industrial Sunset; Stephanie Ross, "Social Unionism in Hard Times: Union-Community Coalition Politics in the CAW Windsor's Manufacturing Matters Campaign," Labour/Le Travail, 68 (Fall 2011): 79-116; and Andy Clark, "'Stealing Our Identity and Taking It over to Ireland': Deindustrialization, Resistance, and Gender in Scotland," in High, MacKinnon, and Perchard, Deindustrialized World, 331-47. 
nationalist position as had happened with workers in southwestern Ontario. Yet even so, it is very difficult to imagine that Cape Bretoners' attachment to the island, as displayed so strongly during the steel crisis, would therefore be fully and even partially eclipsed. The causal importance of the "fighting Cape Bretoner" is inescapable, suggesting the potential value in reconsidering how such collective identities are formed and under what circumstances. Those involved in the steel crisis viewed their struggle in different terms than workers in southwestern Ontario. Moreover, they did not have to wait for middle class creators of culture, nor curators of the tourist gaze, to identify strongly with where they lived and to explain why. Industrial Cape Bretoners were present at their own making. ${ }^{2}$

Collective impulses had long been evident in the industrial zones of the island. External corporate foes, as David Frank and others have illustrated, had been fought before; occupational solidarities, with a sharp class focus, were common. Yet during the period considered by this article the character of collective action assumed a different form. Beginning in the early 1950s, when the coal sector started to buckle, and climaxing in the mid-to-late 196os with the creation of DEVCO and the state purchase of Sydney steel, the regional politics of equality came to the fore, shaping community values and political goals in decisive ways. Viewed one way, industrial Cape Bretoners' broad cast of mind and combined efforts resembled other place-based campaigns for regional equality at the time like Newfoundland's call for "better terms" and Quebec's Quiet Revolution - both of which, in their own ways, sought to harness the power of the federal and provincial state to solve issues of economic (in)equality. Viewed another way, key differences present themselves. The acute and immediate threat of complete economic collapse posed by the hard, ratcheting logic of deindustrialization set Cape Breton's experience apart. So, too, did Nova Scotia's different political and cultural position within the Canadian federation: it had neither Term 29 (Newfoundland) or a distinctive linguistic majority (Quebec) to use as political leverage.

In the historiography of Atlantic Canada, the ascendency of regional equality as a driving political force is typically viewed as the handiwork of politicians, business leaders, bureaucrats, and academics - the "white collar revolutionaries" of the 1950 and 1960 s to borrow from Margaret Conrad. ${ }^{93}$ Yet

92 Here I am thinking of Sean Cadigan's assessment of nationalism in Newfoundland and Labrador: A History (Toronto: University of Toronto Press, 2009) and Ian McKay's classic Quest for the Folk: Antimodernism and Cultural Selection on Twentieth Century Nova Scotia (Montreal and Kingston: McCill-Queen's University Press, 1994). 
as industrial Cape Bretoners' actions after Black Friday suggests, some of the "revolutionaries" wore blue collars. Each and every time steel families (and their supporters) discussed the future of steel, they were also considering the political economy of region in Canada and its vexed relationship to equality both of opportunity and of outcome. It is there in the letters written by working class children, the words of Nelson Muise, the briefs put forth by Local 1064, and editorials in the Cape Breton Post - in that moment, fighting Cape Bretoners all. The discourse on this important relationship was thus deepened considerably, providing tangible examples of experience and struggle out of which future observers, like the activists and scholars interested in the "development of underdevelopment" and attached to publications such as the New Maritimes, Canadian Dimension, and Acadiensis, would craft their own assessments of the region. More tangibly, the campaign to save Sydney steel and Cape Breton coal - helped to establish some of the political mechanisms through which equality of this sort might be realized and, paradoxically, the fiscal limits of what the state could reasonably provide given the heavy costs involved.

The year after DOSCO's steel assets were purchased, the newly created Sydney Steel Corporation (SYSCO) recorded a profitable year. Some locals joked that "Black Friday" had become "Bright Friday." 94 Yet by the early 1970s, the Conservative Party under G.I. Smith was no longer in power, SYSCO was losing money, state expenditures for steel started to climb, and debates over the plant's modernization - involving tens of millions of dollars - ensued. ${ }^{95}$ At the same time, a greater, more public understanding of the human and environmental impacts of steelmaking emerged - provoking intense debates over jobs, justice, health, and the future - while the Liberal government searched in vain for a new owner. In this evolving context, the "fighting Cape Bretoner" would return to public discourse as a new generation sought to protect their island home. The struggle for them would not be against a predatory corporate foe, but to convince both levels of government to clean up the environmental damage produced by nearly a century of steelmaking - a legacy defended by their own community less than a decade before. The transition to a post-industrial reality of some kind was thus underway. While state intervention had reduced the speed of social and economic collapse, it had come at a steep price on many levels. Paradoxically, a collective identity

94 "A Year after Black Friday," Cape Breton Highlander, 9 October 1968.

95 Beck, Politics of Nova Scotia, 309. 


\title{
born in large measure in an industrial crisis would prove very useful to those determined to ameliorate some of industrialization's toxic legacies.
}

\begin{abstract}
ANDREW PARNABY est professeur agrégé d'histoire et doyen de la School of Arts and Social Sciences à I'Université du Cap-Breton. Sa publication la plus récente, "Growing Up Even More Uncertain": Children and Youth Confront Industrial Ruin in Sydney, Nova Scotia, 1967 », a paru dans The Deindustrialized World: Confronting Ruination in Postindustrial Places, publié sous la direction de Steven High, Lachlan MacKinnon et Andrew Perchard (Vancouver, UBC Press, 2017), p. 85-110.
\end{abstract}

ANDREW PARNABY is an associate professor of history and dean of the School of Arts and Social Sciences at Cape Breton University. His most recent publication is "Growing Up Even More Uncertain: Children and Youth Confront Industrial Ruin in Sydney, Nova Scotia, 1967," in The Deindustrialized World: Confronting Ruination in Postindustrial Places, ed. Steven High, Lachlan MacKinnon, and Andrew Perchard (Vancouver: UBC Press, 2017), 85-110. 